\title{
LARUTAN TAPE SINGKONG (Manihot Utilissima) SEBAGAI ATRAKTAN NYAMUK
}

\author{
Eva Mai Sa'adah, Isnawati, Noraida \\ Poltekkes Kemenkes Banjarmasin Jurusan Kesehatan Lingkungan \\ Jl. H. Mistar Cokrokusumo No.1A Banjarbaru Kalimantan Selatan 70714 \\ Email : evamaisaadah@gmail.com
}

\begin{abstract}
The Fermented Cassava (Manihot utilissima) as Atraktan for Mosquito. The use of synthetic insecticides can cause health hazards to humans. Mosquito trap made of disused plastic bottles plus mosquito atraktan from natural materials is an alternative that is more economical, safe and environmentally friendly. One of the mosquito atraktan compounds is $\mathrm{CO}_{2}$. Fermented cassava is potentially as mosquito atraktan because it can produce $\mathrm{CO}_{2}$. This study aimed to know the influence of fermented cassava solutions as atraktan in mosquito trap from plastic bottles on the number of mosquitoes trapped. Type this study was Quasi Experiment. Design this study was Post-test Only with Control Design. The concentration of fermented cassava solutions was used in this study was 0\% (control), $10 \%, 30 \%, 50 \%$ and $70 \%$. The results showed the number of mosquitoes trapped at a concentration of $0 \%$ (control), $10 \%, 30 \%$ and $70 \%$ as much as 0 tail, whereas the konentrasi 50\% as much as 1 tail. Kruskal Wallis test results showed no significant effects of the concentration of fermented cassava solutions.
\end{abstract}

Keywords: Fermented Cassava Solutions; Mosquito Atraktan; Mosquito Trap.

\begin{abstract}
Abstrak: Larutan Tape Singkong (Manihot utilissima) sebagai Atraktan Nyamuk. Penggunaan insektisida sintetis dapat menimbulkan bahaya kesehatan bagi manusia. Alat perangkap nyamuk dari botol plastik bekas ditambah atraktan nyamuk dari bahan alami merupakan alternatif yang lebih ekonomis, aman dan ramah lingkungan. Salah satu senyawa atraktan nyamuk adalah $\mathrm{CO}_{2}$. Tape singkong berpotensi sebagai atraktan nyamuk karena dapat menghasilkan $\mathrm{CO}_{2}$. Penelitian ini bertujuan untuk mengetahui pengaruh larutan tape singkong sebagai atraktan pada alat perangkap nyamuk dari botol plastik terhadap jumlah nyamuk yang terperangkap. Jenis penelitian ini adalah Eksperimen Semu. Rancangan penelitian ini adalah Post-test Only with Control Design. Konsentrasi larutan tape singkong yang digunakan dalam penelitian ini adalah 0\% (kontrol), 10\%, 30\%, 50\% dan $70 \%$. Hasil penelitian menunjukkan jumlah nyamuk yang terperangkap pada konsentrasi 0\% (kontrol), 10\%, 30\% dan, 70\% sebanyak 0 ekor, sedangkan konentrasi 50\% sebanyak 1 ekor. Hasil uji Kruskal Wallis menunjukkan tidak ada pengaruh yang signifikan dari kelima konsentrasi larutan tape singkong tersebut.
\end{abstract}

Kata kunci: Larutan Tape Singkong; Atraktan Nyamuk; Perangkap Nyamuk.

\section{PENDAHULUAN}

Nyamuk merupakan salah satu jenis vektor yang paling banyak dijumpai di Indonesia. Populasi nyamuk di Indonesia cukup banyak dan menjadi penyebab beberapa penyakit penting yang dapat menimbulkan berbagai macam penyakit sehingga mendapat perhatian khusus dari pemerintah. Populasi ini akan meningkat seiring dengan datangnya musim hujan karena banyaknya tempat yang dapat berperan sebagai tempat perindukan dan perkembangbiakan. Tempat yang nyaman juga akan mempermudah nyamuk dalam berkem-bangbiak untuk memperbanyak populasi. Penyakit yang dibawa nyamuk akan menjadi semakin banyak di saat perubahan iklim seperti peralihan musim kemarau ke musim hujan atau sebaliknya[1].

Terdapat berbagai jenis insektisida yang beredar dan dipasarkan dengan bebas. Umumnya insektisida yang diperjualbelikan tersebut adalah insekti-sida yang terbuat dari bahan-bahan kimia. Penggunaan insektisida sintetis yang 
berlebihan dan dalam jangka waktu panjang dapat menimbulkan beberapa kerugian seperti nyamuk menjadi resisten, terjadinya keracunan pada manusia dan hewan ternak, serta polusi lingkungan[2].

Pengembangan metode lain untuk pengendalian nyamuk selain menggunakan insektisida adalah penggunaan alat perangkap nyamuk (mosquito trap). Banyak alat perangkap nyamuk yang diperjualbelikan, yaitu perangkap elektrik tetapi harganya relatif mahal. Contoh alat perangkap nyamuk tersebut adalah perangkap nyamuk black hole, perangkap nyamuk ultraviolet, perangkap nyamuk elektrik insect killer, dan perangkap nyamuk LED super, dengan rentang harga muai dari Rp. 100.000-400.000[3].

Atraktan adalah sesuatu yang memiliki daya tarik terhadap serangga (nyamuk) baik secara kimiawi maupun visual (fisik). Atraktan dari bahan kimia dapat berupa senyawa ammonia, $\mathrm{CO}_{2}$, asam laktat dan asam lemak. Zat atau senyawa tersebut berasal dari bahan organik atau merupakan hasil proses metabolisme makhluk hidup, termasuk manusia. Atraktan dapat digunakan untuk mempengaruhi perilaku, memonitor atau menurunkan populasi nyamuk secara langsung tanpa menyebabkan cedera bagi binatang lain dan manusia, dan tidak meninggalkan residu pada makanan atau bahan pangan. $\mathrm{CO}_{2}$, asam laktat dan octenol merupakan atraktan yang dikenali dengan sangat baik, senyawa yang terbukti mempengaruhi saraf penciuman nyamuk[4].

Dalam proses pembuatan tape singkong terdapat mikroorganisme dari ragi tape yang pada kondisi anaerob akan menghasilkan enzim amilase dan enzim amiloglukosidase, dua enzim yang bertanggungjawab dalam penguraian karbohidrat menjadi maltosa dan glukosa[5]. Kemudian khamir akan merubah sebagian gula-gula tersebut menjadi alkohol. Saccharomyces cerevisiae adalah salah satu spesies khamir pada ragi tape yang memiliki daya konversi gula menjadi etanol sangat tinggi. Saccharomyces cerevisiae merupakan organisme fakultatif anaerob yang dapat menggunakan baik sistem aerob maupun anaerob untuk memperoleh energi dari pemecahan glukosa[6]. Saccharomyces cerevisiae merupakan spesies yang bersifat fermentatif (melakukan fementasi, yaitu memecah glukosa menjadi $\mathrm{CO}_{2}$ dan alkohol) kuat. Tetapi dengan adanya oksigen, Saccharomyces cerevisiae juga dapat melakukan respirasi yaitu mengoksidasi gula menjadi $\mathrm{CO}_{2}$ dan air.

\section{BAHAN DAN CARA PENELITIAN}

Alat perangkap nyamuk dalam penelitian ini terbuat dari botol plastik bekas kemasan 1,5 liter yang diisi dengan larutan tape singkong konsentrasi $0 \%$ (kontrol), 20\%, 30\%, 50\% dan 70\%. Populasi dalam penelitian ini adalah seluruh nyamuk yang berada di sekitar rumah warga Kelurahan Komet RT 01 RW 06, Kecamatan Banjarbaru Utara, Kota Banjarbaru. Sampel dalam penelitian ini adalah nyamuk yang terperangkap dari hasil penangkapan menggunakan alat perangkap nyamuk yang mewakili seluruh populasi.

Jenis penelitian ini adalah Eksperimen Semu (Quasi Eksperiment) yang bertujuan mengetahui pengaruh larutan tape singkong sebagai atraktan pada perangkap nyamuk dari botol plastik terhadap jumlah nyamuk yang terperangkap. Desain yang digunakan pada penelitian ini adalah Post-test Only with Control Design. Dalam desain penelitian ini terdapat dua kelompok, yaitu kelompok yang diberi perlakuan khusus disebut kelompok eksperimen $\left(\mathrm{X}_{1,2,3,4}\right)$ dan kelompok yang tidak diberi perlakuan khusus disebut kelompok kontrol $\left(\mathrm{X}_{0}\right)$. Kemudian pengaruh dari adanya perlakukan diamati/diobservasi (0). Analisis bivariat dilakukan dengan menggunakan uji Kruskal Wallis.

Alat perangkap nyamuk dipasang pada rumah warga selama 72 jam. Setelah 72 jam, dilakukan pengukuran suhu dan kelembaban (RH) pada tempat pemasangan alat perangkap nyamuk serta pemeriksaan pada alat perangkap nyamuk. Nyamuk yang terperangkap dihitung dan diidentifikasi jenisnya. 


\section{HASIL PENELITIAN DAN PEMBAHASAN}

Penelitian ini dilaksanakan di Kelurahan Komet. Kelurahan Komet merupakan salah satu kelurahan di Kecamatan Banjarbaru Utara Kota Banjarbaru yang dinyatakan endemis DBD pada tahun 2014 hingga akhir bulan September
2016[8]. Kelurahan Komet memiliki luas \pm 244 Ha. Kelurahan Komet terdiri dari 19 RT dan 6 RW[9]. Penelitian ini memerlukan 5 buah rumah sebagai tempat untuk menguji coba alat perangkap nyamuk, sehingga peneliti hanya melakukan penelitian di Kelurahan Komet RT 01 RW 06.

Tabel 1. Nyamuk Yang Terperangkap Pada Alat Perangkap Nyamuk Berisi Larutan Tape Singkong Konsentrasi 0\%

\begin{tabular}{ccccccc}
\hline & \multicolumn{3}{c}{ Dalam Rumah } & \multicolumn{4}{c}{ Luar Rumah } \\
Rumah & $\begin{array}{c}\sum \text { Nyamuk yg } \\
\text { Terperangkap } \\
\text { (Ekor) }\end{array}$ & $\begin{array}{c}\text { Suhu } \\
\left({ }^{\circ} \mathrm{C}\right)\end{array}$ & $\begin{array}{c}\mathrm{RH} \\
(\%)\end{array}$ & $\begin{array}{c}\sum \text { Nyamuk yg } \\
\text { Terperangkap } \\
\text { (Ekor) }\end{array}$ & $\begin{array}{c}\text { Suhu } \\
\left({ }^{\circ} \mathrm{C}\right)\end{array}$ & $\begin{array}{c}\mathrm{RH} \\
(\%)\end{array}$ \\
\hline 1 & 0 & 28 & 86 & 0 & 30 & 82 \\
2 & 0 & 28 & 86 & 0 & 30 & 83 \\
3 & 0 & 29 & 85 & 0 & 30 & 81 \\
4 & 0 & 29 & 85 & 0 & 30 & 83 \\
5 & 0 & 29 & 86 & 0 & 30 & 81 \\
Jumlah & 0 & & & 0 & 30 & 82 \\
Rata-Rata & & 28,6 & 85,6 & & 30 \\
\hline
\end{tabular}

Tabel 1 menunjukkan secara berturut-turut tidak ditemukan satupun nyamuk yang terperangkap pada alat perangkap nyamuk berisi larutan tape singkong konsentrasi 0\% (kontrol) yang dipasang di dalam maupun di luar rumah.
Rata-rata suhu tertinggi pada tempat pemasangan alat perangkap ini berada di luar rumah $\left(30^{\circ} \mathrm{C}\right)$, sedangkan rata-rata kelembaban tertinggi berada di dalam rumah $(85,6 \%)$.

Tabel 2. Nyamuk yang Terperangkap Pada Alat Perangkap Nyamuk Berisi Larutan Tape Singkong Konsentrasi $10 \%$

\begin{tabular}{ccccccc}
\hline & \multicolumn{3}{c}{ Dalam Rumah } & \multicolumn{4}{c}{ Luar Rumah } \\
Rumah & $\begin{array}{c}\sum \text { Nyamukyg } \\
\text { Terperangkap } \\
\text { (Ekor) }\end{array}$ & $\begin{array}{c}\text { Suhu } \\
\left({ }^{\circ} \mathrm{C}\right)\end{array}$ & $\begin{array}{c}\mathrm{RH} \\
(\%)\end{array}$ & $\begin{array}{c}\sum \text { Nyamuk yg } \\
\text { Terperangkap } \\
\text { (Ekor) }\end{array}$ & $\begin{array}{c}\text { Suhu } \\
\left({ }^{\circ} \mathrm{C}\right)\end{array}$ & $\begin{array}{c}\mathrm{RH} \\
(\%)\end{array}$ \\
\hline 1 & 0 & 28 & 85 & 0 & 30 & 82 \\
2 & 0 & 28 & 86 & 0 & 30 & 83 \\
3 & 0 & 29 & 85 & 0 & 30 & 81 \\
4 & 0 & 29 & 85 & 0 & 30 & 83 \\
5 & 0 & 28 & 86 & 0 & 30 & 81 \\
Jumlah & 0 & & & 0 & 30 & 82 \\
Rata-Rata & & 28,4 & 85,4 & & 30 \\
\hline
\end{tabular}

Tabel 2 menunjukkan secara berturut-turut tidak ditemukan satupun nyamuk yang terperangkap pada alat perangkap nyamuk berisi larutan tape singkong konsentrasi $10 \%$ yang dipasang di dalam maupun di luar rumah. Rata-rata suhu tertinggi pada tempat pemasangan alat perangkap ini berada di luar rumah $\left(30^{\circ} \mathrm{C}\right)$, sedangkan rata-rata kelembaban tertinggi berada di dalam rumah $(85,4 \%)$. 
Tabel 3. Nyamuk yang Terperangkap Pada Alat Perangkap Nyamuk Berisi Larutan Tape Singkong Konsentrasi 30\%

\begin{tabular}{ccccccc}
\hline & \multicolumn{3}{c}{ Dalam Rumah } & \multicolumn{4}{c}{ Luar Rumah } \\
Rumah & $\begin{array}{c}\sum \text { Nyamukyg } \\
\text { Terperangkap } \\
\text { (Ekor) }\end{array}$ & $\begin{array}{c}\text { Suhu } \\
\left({ }^{\circ} \mathrm{C}\right)\end{array}$ & $\begin{array}{c}\text { RH } \\
(\%)\end{array}$ & $\begin{array}{c}\sum \text { Nyamuk yg } \\
\text { Terperangkap } \\
\text { (Ekor) }\end{array}$ & $\begin{array}{c}\text { Suhu } \\
\left({ }^{\circ} \mathrm{C}\right)\end{array}$ & $\begin{array}{c}\mathrm{RH} \\
(\%)\end{array}$ \\
\hline 1 & 0 & 28 & 85 & 0 & 30 & 83 \\
2 & 0 & 28 & 86 & 0 & 30 & 83 \\
3 & 0 & 29 & 85 & 0 & 30 & 81 \\
4 & 0 & 29 & 86 & 0 & 30 & 82 \\
5 & 0 & 28 & 86 & 0 & 30 & 81 \\
Jumlah & 0 & & & 0 & 30 & 82 \\
Rata-Rata & & 28,4 & 85,6 & & 30 \\
\hline
\end{tabular}

Tabel 3 menunjukkan secara berturut-turut tidak ditemukan satupun nyamuk yang terperangkap pada alat perangkap nyamuk berisi larutan tape singkong konsentrasi $30 \%$ yang dipasang di dalam maupun di luar rumah. Rata-rata suhu tertinggi pada tempat pemasangan alat perangkap ini berada di luar rumah $\left(30^{\circ} \mathrm{C}\right)$, sedangkan rata-rata kelembaban tertinggi berada di dalam rumah $(85,6 \%)$.

Tabel 4. Nyamuk yang Terperangkap Pada Alat Perangkap Nyamuk Berisi Larutan Tape Singkong Konsentrasi 50\%

\begin{tabular}{ccccccc}
\hline & \multicolumn{3}{c}{ Dalam Rumah } & \multicolumn{4}{c}{ Luar Rumah } \\
Rumah & $\begin{array}{c}\sum \text { Nyamuk yg } \\
\text { Terperangkap } \\
\text { (Ekor) }\end{array}$ & $\begin{array}{c}\text { Suhu } \\
\left({ }^{\circ} \mathrm{C}\right)\end{array}$ & $\begin{array}{c}\text { RH } \\
(\%)\end{array}$ & $\begin{array}{c}\text { N Nyamuk yg } \\
\text { Terperangkap } \\
\text { (Ekor) }\end{array}$ & $\begin{array}{c}\text { Suhu } \\
\left({ }^{\circ} \mathrm{C}\right)\end{array}$ & $\begin{array}{c}\text { RH } \\
(\%)\end{array}$ \\
\hline 1 & 0 & 28 & 86 & 0 & 30 & 82 \\
2 & 0 & 28 & 86 & 1 & 30 & 83 \\
3 & 0 & 29 & 85 & 0 & 30 & 81 \\
4 & 0 & 28 & 85 & 0 & 30 & 82 \\
5 & 0 & 29 & 86 & 0 & 30 & 81 \\
Jumlah & 0 & & & 1 & 30 & 81,8 \\
Rata-Rata & & 28,4 & 85,6 & & & \\
\hline
\end{tabular}

Tabel 4 menunjukkan secara berturut-turut tidak ditemukan satupun nyamuk yang terperangkap pada alat perangkap nyamuk berisi larutan tape singkong konsentrasi $50 \%$ yang dipasang di dalam rumah. Sedangkan pada alat perangkap yang dipasang di luar rumah hanya ditemukan 1 ekor nyamuk yang terpe- rangkap. Rata-rata suhu tertinggi pada tempat pemasangan alat perangkap ini berada di luar rumah $\left(30^{\circ} \mathrm{C}\right)$, sedangkan rata-rata kelembaban tertinggi berada di dalam rumah $(85,6 \%)$. Berdasarkan hasil idnetifikasi, jenis nyamuk yang terperangkap pada alat ini adalah nyamuk Culex $s p$ (betina). 
Tabel 5. Nyamuk yang Terperangkap Pada Alat Perangkap Nyamuk Berisi Larutan Tape Singkong Konsentrasi 70\%

\begin{tabular}{ccccccc}
\hline & \multicolumn{3}{c}{ Dalam Rumah } & \multicolumn{4}{c}{ Luar Rumah } \\
Rumah & $\begin{array}{c}\sum \text { Nyamuk yg } \\
\text { Terperangkap } \\
\text { (Ekor) }\end{array}$ & $\begin{array}{c}\text { Suhu } \\
\left({ }^{\circ} \mathrm{C}\right)\end{array}$ & $\begin{array}{c}\text { RH } \\
(\%)\end{array}$ & $\begin{array}{c}\sum \text { Nyamuk yg } \\
\text { Terperangkap } \\
\text { (Ekor) }\end{array}$ & $\begin{array}{c}\text { Suhu } \\
\left({ }^{\circ} \mathrm{C}\right)\end{array}$ & $\begin{array}{c}\mathrm{RH} \\
(\%)\end{array}$ \\
\hline 1 & 0 & 28 & 86 & 0 & 30 & 83 \\
2 & 0 & 28 & 85 & 0 & 30 & 83 \\
3 & 0 & 29 & 85 & 0 & 30 & 81 \\
4 & 0 & 29 & 86 & 0 & 30 & 82 \\
5 & 0 & 29 & 86 & 0 & 30 & 81 \\
Jumlah & 0 & & & 0 & 30 & 82 \\
Rata-Rata & & 28,6 & 85,6 & & & \\
\hline
\end{tabular}

Tabel 5 menunjukkan secara berturut-turut tidak ditemukan satupun nyamuk yang terperangkap pada alat perangkap nyamuk berisi larutan tape singkong konsentrasi $70 \%$ yang dipasang di dalam maupun di luar rumah. Rata-rata suhu udara tertinggi pada tempat pemasangan alat perangkap ini berada di luar rumah $\left(30^{\circ} \mathrm{C}\right)$, sedangkan rata-rata kelembaban tertinggi berada di dalam rumah $(85,6 \%)$.

Tabel 6. Hasil Uji Kruskal Wallis

\begin{tabular}{lc}
\hline & Jumlah Nyamuk yang Terperangkap \\
\hline Chi-Square & 4,000 \\
Df & 4 \\
Asymp. Sig. & 0,406 \\
\hline
\end{tabular}

Tabel 6 menunjukkan tidak ada pengaruh dari berbagai konsentrasi larutan tape singkong pada alat perangkap nyamuk terhadap jumlah nyamuk yang terperangkap, karena nilai p-value $(0,406)>\alpha(0,05)$. Tidak signifikannya hasil penelitian ini kemungkinan disebabkan beberapa faktor yaitu:

1. Suhu pada tempat pemasangan alat perangkap nyamuk

Rata-rata suhu optimum untuk pertumbuhan nyamuk $25-27^{\circ} \mathrm{C}[10]$. Sedangkan suhu pada tempat pemasangan alat perangkap nyamuk berkisar antara $28-30^{\circ} \mathrm{C}$. Sehingga suhu kemungkinan mempengaruhi jumlah nyamuk yang terperangkap pada alat perangkap nyamuk dalam penelitian ini.

2. Kurangnya kadar gula dalam larutan tape singkong

Tape singkong dengan perlakuan fermentasi secara alami dapat menghasilkan kadar total gula sebesar 18,2\% [11]. Hal ini berarti bahwa dalam 100 gr tape singkong yang difermentasi secara alami terdapat $\pm 18,2$ gr gula. Berat bahan tape singkong dalam penelitian ini adalah 20 gr, 60 gr, 100 gr dan 140 gr. Sehingga kemungkinan kadar gula pada bahan uji coba dapat dihitung dengan rumus sebagai berikut:

Kadar Gula Bahan Uji Coba $=\frac{18,2 \text { gr } \times \text { Berat Bahan Uji Coba }(\mathrm{gr})}{100 \mathrm{gr}}$ 
Berdasarkan persamaan (1), diketahui kemungkinan kadar gula pada tape singkong seberat 20 gr adalah $3,64 \mathrm{gr}, 60$ gr adalah 10,92 gr, $100 \mathrm{gr}$ adalah 18,2 gr dan 140 gr adalah
25,48 gr. Sedangkan persentase kemungkinan kadar gula dalam larutan tape singkong konsentrasi $10 \%, 30 \%$, $60 \%$ dan $70 \%$ dapat dihitung dengan rumus sebagai berikut:

$\%$ Kadar Gula dalam Larutan Tape Singkong $=\frac{\text { Kadar Gula }(\mathrm{gr})}{\text { Volume Larutan }(\mathrm{ml})} \times 100 \%$

Berdasarkan persamaan (2), diketahui kemungkinan persentase kadar gula terlarut dalam larutan tape singkong konsentrasi $10 \%$ sebanyak $1,82 \%, 30 \%$ sebanyak 5,46\%, 50\% sebanyak $9,1 \%$ dan $70 \%$ sebanyak 12,74\%. Hasil tersebut menunjukkan bahwa kadar gula dalam larutan tape singkong masih kurang untuk dapat menghasilkan gas $\mathrm{CO}_{2}$ yang efektif sebagai atraktan nyamuk, karena menurut penelitian Astuti dan Nusa (2009) untuk menghasilkan gas $\mathrm{CO}_{2}$ yang efektif sebagai atraktan nyamuk diperlukan larutan gula konsentrasi $25 \%$ dan 1 gr ragi (Saccharomyces cerevisiae)[12].

3. Penelitian ini memiliki kelemahan dan keterbatasan yaitu suhu dalam pembuatan tape singkong tidak dikendalikan, kadar $\mathrm{CO}_{2}$ pada larutan tape singkong tidak diukur, tempat penelitian belum mendukung bionomik seluruh jenis nyamuk, pemeriksaan alat perangkap nyamuk serta pengukuran suhu dan kelembaban pada tempat pemasangan alat perangkap nyamuk hanya dilakukan pada waktu ke 72 jam pemasangan alat perangkap (tidak berkala) dan uji coba alat perangkap nyamuk dilakukan langsung di rumah warga sehingga variabel pengganggu seperti suhu dan kelembaban pada tempat pemasangan alat perangkap nyamuk sulit untuk dikendalikan.

\section{KESIMPULAN DAN SARAN}

Jumlah nyamuk yang terperangkap pada alat perangkap nyamuk berisi larutan tape singkong konsentrasi $0 \%$ (kontrol), 10\%, 30\%, dan 70\% sebanyak
0 ekor. Sedangkan pada alat perangkap nyamuk berisi larutan tape singkong konsentrasi 50\% sebanyak 1 ekor. Hasil uji Kruskal Wallis menunjukkan tidak ada pengaruh dari berbagai konsentrasi larutan tape singkong sebagai atraktan pada alat perangkap nyamuk dari botol plastik terhadap jumlah nyamuk yang terperangkap.

Penelitian lanjutan terkait pengaruh penambahan larutan gula pada tape singkong dan pengaruh tape singkong tanpa dilarutkan dengan air sebagai atraktan nyamuk serta meneliti alternatif bahan alami lain yang mampu menghasilkan senyawa-senyawa seperti $\mathrm{CO}_{2}$, asam laktat dan octenol yang berfungsi sebagai atraktan nyamuk. Dalam penelitian tersebut peneliti sebaiknya mengukur kadar senyawa atraktan yang akan terbentuk dan mengontrol semua variabel luar yang dapat mempengaruhi hasil penelitian.

\section{KEPUSTAKAAN}

1. Suharmiati dan Lestari. 2006. Tanaman Obat dan Ramuan Tradisional untuk Mengatasi Demam Berdarah Dengue. Argomedia.

2. Yunita EA, Suprapti NH dan Hidayat JW. 2009. Pengaruh Ekstrak Daun Teklan (Eupatorium riparium) terhadap Mortalitas dan Perkembangan Larva Aedes aegypti: Jurnal Bioma 11:11-17.

3. Kurniati A. 2015. Efektivitas Fermentasi Gula Sebagai Atraktan Nyamuk. Universitas Sumatera Utara, Medan. repository.usu.ac.id. Diakses 25 Januari 2017.

4. Sayono. 2008. Pengaruh Modifikasi Ovitrap Terhadap Jumlah Nyamuk 
Aedes yang Terperangkap. Tesis Fakultas Kesehatan Masyarakat Universitas Diponegoro. Semarang.

5. Kementerian Pertanian Badan Penyuluhan dan Pengembangan Sumber Daya Manusia Pertanian. 2016. Pembuatan Alkohol dari Kulit Tebu Dengan Ragi Saccharomyces cerevisiae. http://cybex.pertanian.go.id/ materipenyuluhan/detail/10625/pe mbuatan-alkohol-dari-kulit-tebu-dengan-ragi-saccharomyces-cerevisiae. Diakses 1 Februari 2017.

6. Elevri PS. 2006. Pemanfaatan bioetanol sebagai bahan bakar pengganti bensin: Jurnal Teknik UNDIP. Semarang.

7. Ridha RM, Nita R, Nur AR dan Dian ES. 2013. Hubungan kondisi lingkungan dan kontainer dengan keberadaan jentik nyamuk Aedes aegypti di daerah endemis DBD di Kota Banjarbaru: Jurnal Epidemiologi dan Penyakit Bersumber Binatang, vol. 4, 3:133137.

8. Data Pemetaan DBD Kota Banjarbaru tahun 2014 - September 2016.
9. BPS Banjarbaru. 2011. Gambaran Umum Wilayah Kota Banjarbaru Tahun 2011. ppsp.nawasis.info/ dokumen/.../bp/...banjarbaru/BPSBANJARBARU-02\%200k.pdf. Diakses 4 Juli 2017.

10. Yudhastuti R dan Vidiyani A. 2005. Hubungan kondisi lingkungan, kontainer, dan perilaku masyarakat dengan keberadaan jentik nyamuk Aedes aegypti di daerah endemis demam berdarah dengue Surabaya. Jurnal Kesehatan Lingkungan Vol. 1 no. 2 Januari 2005: 170-182

11. Asnawi M, Sumarlan SH dan Hermanto MB. 2013. Karakteristik tape ubi kayu (Manihot utilissima) melalui proses pematangan dengan penggunaan pengontrol suhu: Jurnal Bioproses Komoditas Tropis, Vol. 1 No. 2, 56-66.

12. Astuti EP dan S Roy Nusa RE. 2009. Efektifitas Alat Perangkap (Trapping) Nyamuk Vektor Demam Berdarah Dengue dengan Fermentasi Gula. Portalgaruda.org/article.php?article= $78877 \& \mathrm{val}=4901$. Diakses 25 Januari 2017. 
